\title{
Basic Social Services for Ethnic Minority Groups in Urban of Vietnam: Current Situation and Solutions
}

\author{
Tran Van Kham ${ }^{1}$, Nguyen Van Chieu ${ }^{2}$ \\ ${ }^{1}$ Office for Research Affairs, VNU University of Social Sciences and Humanities, Hanoi, Vietnam \\ ${ }^{2}$ Center for Quality Assurance, VNU University of Social Sciences and Humanities, Hanoi, Vietnam
}

\section{Email address:}

khamtv@ussh.edu.vn (T. V. Kham),nguyenchieu5579@yahoo.com (N. V. Chieu)

\section{To cite this article:}

Tran Van Kham, Nguyen Van Chieu. Basic Social Services for Ethnic Minority Groups in Urban of Vietnam: Current Situation and Solutions. Humanities and Social Sciences. Vol. 4, No. 6, 2016, pp. 173-180. doi: 10.11648/j.hss.20160406.17

Received: November 3, 2016; Accepted: November 16, 2016; Published: December 16, 2016

\begin{abstract}
At the moment, there is about 13 million of ethnic minorities living in the urban areas of Vietnam, facing difficulties on their daily life. In order to improve the life quality, the narrow the gap between the minorities and majority in Vietnam, this paper aims at identifying the welfare accessibilities by minorities in the urban life in terms of housing, health care services, employment services and public services as well; and proposing the solutions for improving such conditions to have better life of minorities in the urban. Based on the sustainable livelihood framework as the theoretical approach, and the survey with 600 ethnic minorities, at the age of 18 and above, in three provinces of Vietnam, it is found that the ethnic minorities are facing difficulties on accessing the basic social services due to many limitations, from such this paper also suggests the considerations improving the life conditions for ethnic minorities in Vietnam in the urban life from perspective of social welfare and sustainable development.
\end{abstract}

Keywords: Social Services, Vietnam, Minorities, Access, Urban Life

\section{Introduction}

Vietnam is multi cultural background countries with 53 minorities. Each group has its own characteristics of economic, cultural and language. They are living mostly in the rural, mountainous and remote areas in less developed life conditions. There are about 13.5 millions of ethnic minority people living in around 3100 households among 63 provinces of Vietnam; it increases $1.55 \%$ in last 10 years [9]. And in the urbanization and industrialization process, the number of those minorities living in the urban areas increases at around 1.5 million $(10.5 \%$ of the whole national minorities). Recent reports by Vietnam National Committee on Ethnic Minority Affairs and General Office Statistics show that the ethnic minorities groups living in difficulties as if they are experiencing their life in the urban areas, it is suggested that further research about the life condition of ethnic minorities in the contemporary urban of Vietnam [9]. This paper, is a part of national research project funded by Vietnam National Committee on Ethnic Minority Affairs, titled: Life of Ethnic Minority Groups in Urban and
Industrial Zones in Vietnam: Current situation and proposal solutions (2016), aims at identifying the current situation of ethnic minority groups in accessing the basic social services in urban life and proposing the solutions for better life condition of these groups.

\section{Literature Reviews}

Daily life experience of ethnic minorities has been an attractive research topic, in sociology, management science, and anthropology as well or from interdisciplinary approach as these groups are facing difficulties as their lack of capacities and opportunities to get the better life conditions. Although there are current discussions on the life improvement, social research indentifying their life in urban areas are still limited as the following considerations: In the urban, the poor is vulnerable as the decline of living environment [32], while there is less updated and accessible policy for them in the urban life. So, in order to reduce the 
risks for the poor in general and for the minorities in particular, it is suggested to have well-designed policies which are contextual and practical in line with the current economic, social and cultural conditions in the urban areas. In Vietnam, the questions for meeting the welfare needs of the society in general and of the minorities in particular are necessary for the better livelihood [21]. In addition, $\mathrm{Vu}$ Van Phuc (2012), in discussion of the prospects of welfare practice in Vietnam to 2020, emphasized the ways on guarantee the social welfare have been the cored action plan for social development as the same aim of social development strategy [31: 13-14]. The implementation of such aims needs more solutions, in terms of social policies by the State as closed relationship between social development and social equality in the designing step and implementing stages of every social policies and welfare practices, and developing multi-forms of social insurances and medicare [31: 92], promoting the administrative role of central and local government on implementing, supervising and advocating policies for such purposes. It seems that the recent research present efforts on improving the welfare for the poor in general and for minorities for the sustainable development in Vietnam [17].

Additionally, there are research directions on the daily life conditions of ethnic minorities in the urban and industrial zones in Vietnam. The first one includes the national surveys such as national census, household living standards with the sole aim on urban economics, or urban planning, urban culture and life styles which draw the specific characteristics of daily urban life, with less consideration on the general themes for the whole country. In this research direction, the migration flow has been considered [11]. Besides, the second on on research about the impacts by urbanization and industrialization process have been noted in the urban life of minority groups as the cultural problems [26, 27]; labor engagement and relationship [23], social supports and policies for specific groups in urbanization [3] which express the directions on urban planning, economic development of urban in mountainous areas, specific solutions on poverty alleviation and literacy improvement, respect about the culture and customs of each ethnic minority group. Other research also considers to the role of workers on industrial zones, and promotion the local workers on the industrialization process $[18,22]$. In such research topic, La Thi Thu Thuy et al (2011) also looked at the metal changes and problems of local workers in the industrial zone and work places [10]. Tran Thanh Nam presented findings about the daily life of Khmer in the urban and in the innovation of Vietnam [25], while Nguyen Minh Tuan showed the daily life of Ede in the Highland of Vietnam, it illustrated the view of the life of Ede in terms of economics (infrastructure, housing, living facilities, household incomes) and noneconomics (education, healthcare, community participation and gender equality) [18]. In additions, Nguyen Van Quyet also emphasized on the changes and impacts of urban life to the cultural and belief spheres of the minorities [19], and which also leads to the social inclusion process of the minorities as the social services usage [28, 19, 30], or community participation [24].

It is hard to find the current perspectives and research directions about the accessibilities to social services in the daily life of minorities in urban, and how to find the best ways to make their life better in the urban.

\section{Research Methods}

\subsection{Methodology}

This paper applies the approach of human development as the first one which aims at identifying any possible opportunities for the subjects to self-improve their life conditions sustainably [33]. This approach looks at the capacities to live which are significant and unique. In the developing process, Vietnam is facing the trap of middle income as the poor infrastructure, dilemma between the aims and means of social development, the low skill human resources. So, Vietnam considers not only the increase of income but also the improvement of educational, healthcare services and employment opportunities as well [32]. The second approach related to the human capital and social capital. The former implies the potentiality and potential improvement of health quality, personal knowledge as significant tools for the future benefits of a person and a national as a whole. It is suggested as the significant factor to create the higher income and living standard, especially for the poor [20:5]. This is the notable definition on making the theoretical framework on researching the daily life experiences of the minorities in the urban. The latter is known as the interrelationship of family, relatives, community and society of each individual and family which enrich them the abilities to improve the life condition. It is significant approach but still limited in researching the minorities in Vietnam. The third one is developed from the sustainable livelihood by Department for International Development, United Kingdom (DFID) in 1999 and currently applied in anthropological research [20]. There are 5 components making the first idea of this framework: (a) the personal priorities, (b) the personal strategy for such priority list; (c) institutions and policies impact the personal access to the existed opportunities and asserts; (d) personal accessibility to the social resources, (e) life conditions including economics, technology, population [1: 6]. The second aspect of the framework covers the perspective of central position of person and personal livelihood in the development. The third one accepts the view on the role of policy, institutions on human resources accessibility and livelihood impacts [8: 3]. The fourth one identifies the livelihood from the property perspective and capital as significant took for the minorities on their new life experiences in the urban [2: 2039]. The fifth one illustrates the weakness and strengths of this framework on doing research [12: 55; 20].

Besides such framework, Tran Van Kham overviews the social inclusion's approach and its application on doing social 
research in Vietnam, and presents some indicators in such research: social pressure, healthcare, community safety, economics and community participation [28: 39]. These indicators are significant to search for the social inclusion of each person in the existed social conditions. Based on such approaches, this paper identifies the life experiences of the minorities in the urban through their accessibility to social services.

\subsection{Research Methods}

This paper, as a part of research project, applies (a) the documentary analysis (with more focuses on legal and social policy documents about the urbanization, industrialization; recent research works about the ethnic minorities in general and in the urban in particulars, other official reports by the Committee on Minorities and General Statistics Office); (b) survey with 600 ethnic minorities in three provinces of Thai Nguyen, Binh Duong and Dac Lac for those above 18 years old, aims at identifying the impacted factors for their life in the urban.

The sample of the survey is presented in the following table:

Table 1. Sample of survey.

\begin{tabular}{|c|c|c|c|}
\hline & & $\mathbf{N}$ & $\%$ \\
\hline \multirow{3}{*}{1} & Gender & 599 & 100 \\
\hline & Male & 294 & 49.1 \\
\hline & Female & 305 & 50.9 \\
\hline \multirow{5}{*}{2} & Marital status & 598 & 100 \\
\hline & Not married & 177 & 29.6 \\
\hline & Married & 397 & 66.4 \\
\hline & Divorce & 10 & 1.7 \\
\hline & Widow & 14 & 2.3 \\
\hline \multirow{4}{*}{3} & Age group & 598 & 100 \\
\hline & Under 30 & 303 & 50.7 \\
\hline & From 30 to under 45 & 190 & 31.8 \\
\hline & Above 45 & 105 & 17.5 \\
\hline \multirow{3}{*}{4} & Residential status & 599 & 100 \\
\hline & Migrated & 238 & 39.7 \\
\hline & Permanent & 361 & 60.3 \\
\hline \multirow{4}{*}{5} & Places & 601 & 100 \\
\hline & Thai Nguyen & 200 & 33.3 \\
\hline & Dac Lac & 201 & 33.4 \\
\hline & Binh Duong & 200 & 33.3 \\
\hline
\end{tabular}

\section{Findings}

\subsection{Current Situation of Accessing Social Services by Minorities in the Urban}

In general, the basic social services for minorities include: housing, water, environment safety, education, health care, cultural and recreational activities, etc. They are the basic and fundamental for the daily life of each person to live and work in the urban conditions. Social services in urban are so important which contribute to the realization of social policies and transfer the social development plan into actions; and to balance the contribution and social benefits among the citizen groups; to protect the accessible rights to basic services for all, especially for the vulnerable groups. Such activities make the better and stronger social security network and sustainable development of urban [4]. So, social services accessibility is a key indicator for understanding the social inclusion and inclusive life conditions for all [28; 29; 30]. In last decades, although many social policies have been made for the urban as the requirements of urbanization and urban development, a large part of urban in general and urban minorities in particular have been not fully accessible to them which provided by the States and other organizations. Its pressures have been stronger as the urban development and the requirements for better life conditions. Findings from the survey in three parts of Vietnam and the national survey in the life condition of 53 minority groups in Vietnam [9] show that the current situation of accessing such services are demonstrated in the following aspects:

\subsubsection{Housing, Clean Water and Environmental Sanitation}

Survey findings with 600 participants in three parts of Vietnam show that almost local ethnic minorities live in the private houses while the migrants stay in the rental (51\%). There is less evidence showing that they are living in the dormitories of the industrial zones, with the acquaintance friends or relatives or the landlord. The ratio of ethnic minority groups access to the workplace dormitory is so small $(0.7 \%)$ among respondents while discussing the housing demands.

Table 2. Form of housing (\%).

\begin{tabular}{ll|l|l}
\hline & Housing & N & \% \\
\hline 1 & Living in relative house & 26 & 4.3 \\
2 & Living with landlord & 15 & 2.5 \\
3 & Rental house & 304 & 50.6 \\
4 & Private house & 230 & 38.3 \\
5 & Industrial park's dormitory & 4 & 0.7 \\
6 & Other & 22 & 3.7 \\
\hline
\end{tabular}

Source: Survey findings

The privacy on using the housing facilities by ethnic minority groups has been responded differently. It is found that the minorities share the bathroom and toilet more than private using (around 4 times). It means that there is low accessibility to the private usage of such facilities by ethnic minorities in the urban life. Many can prepare meals everyday by themselves in the shared facilities.

Table 3. Using the facilities (\%).

\begin{tabular}{lllll}
\hline & Facilities & Sharing & Owning & Not use \\
\hline 1 & Bathroom & 53.1 & 46.4 & 0.5 \\
2 & Kitchen & 25.8 & 71.9 & 2.4 \\
3 & Toilet & 53.1 & 44.9 & 2.0 \\
\hline
\end{tabular}

Source: Survey findings

Accessing the clean water and using the standard toilets for ethnic minority groups in urban are still difficult. The 
survey findings about accessibilities to the environmental conditions, clean water by the ethnic minority groups in the living areas are shown that they are living in the bad and wet conditions (mean=2.43); lack of clean water (mean=2.27); bad condition of water supplied systems (mean=2.27); poor environmental sanitation (mean=2.28); dirty and overloaded toilet $(\text { mean }=2.23)^{1}$. It means that the quality of living environment is one of the most consideration problems which need further improvements for better life quality for ethnic minority groups in the urban.

\subsubsection{Health Care and Primary Care}

It is a common habit of the ethnic minorities on buying medicines and self-treating while they are in sick. When ethnic minorities are in health troubles, a majority goes to pharmacy to buy the medicines for self-treatment (account $53.4 \%$ ), or visit the commune clinics (nearly $50 \%$ ), while there is low response for public and private clinics at $25.3 \%$ and $25.2 \%$ respectively. It shows that the ethnic minority groups are familiar with self-treatment or visit the local doctors rather than using the higher cost services of district, provincial hospitals or the private clinics.

Table 4. Using the medical services (\%).

\begin{tabular}{llll}
\hline & Using the medical services & N & \% \\
\hline 1 & Commune clinics & 212 & 46.9 \\
2 & Workplace clinics & 121 & 23.9 \\
3 & Private hospitals & 112 & 26.9 \\
4 & Self-treatment & 229 & 53.4 \\
5 & Visit local doctor/nurse & 15 & 3.7 \\
6 & District hospitals & 83 & 19.6 \\
7 & Public hospital & 107 & 25.3 \\
8 & Private clinics & 106 & 25.2 \\
9 & Back to hometown & 11 & 2.7 \\
10 & Other & 7 & 1.7 \\
\hline
\end{tabular}

Source: Survey findings

In terms of insurance usage, survey findings present that the ethnic minority groups less prefer the forms of insurance in general and in health insurance in particular while they live in their homeland (for the migrated minorities) or in the past (for the local minorities in the urban). However, at the current life, they pay more attention on any forms of insurance, with two times of using the health insurance as before.

So, it is clear that the increased ratio on health insurance registration also presents that the change of urban life brings the significant impacts to the understanding and practicing of ethnic minority groups about the role of health insurance in general and specific insurance policies in particular.

${ }^{1}$ this mean is developed from 5 scale of Likert, so the gap for each mean value is calculated by (5-1): $5=0.8$, i.e: from 1 to under 1.8 : very difficulty; from 1.8 to under 2.6: difficulty; from 2.6 to under 3.4 : average; from 3.4 to under 4.2 : advantage; above 4.2 : very advantage

\subsubsection{Education Services}

It is found that there is a majority of responses at average level on educational services in the community, in which there is more advantage on educational permission for children in schools (mean=3.46), however such ratio for the public schools is lower with mean at 2.97, and the lowest ratio to educational service in the urban life is at the vocational training, with mean at 2.73. Although, such responses to three forms of educational services for ethnic minorities are at the normal ratio while look at the mode value statistically, standing around 3 .

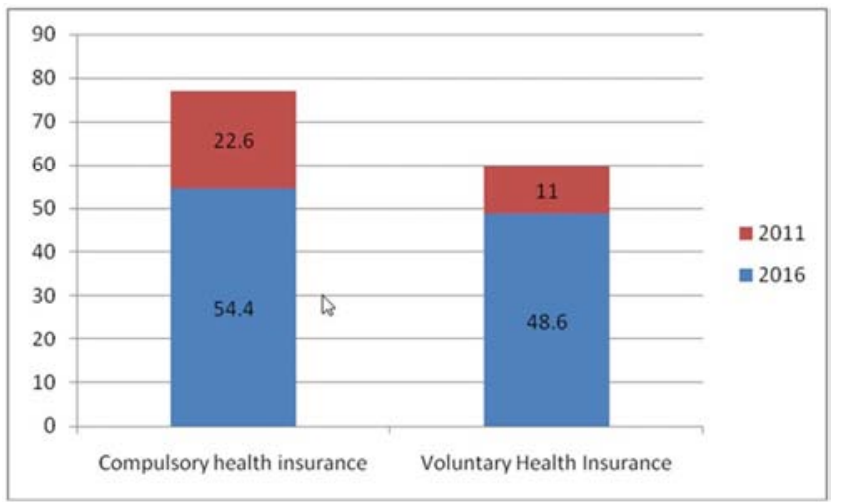

Source: Survey findings

Figure 1. Using the health insurance (\%).

\subsubsection{Cultural Activities, Sports and Recreation in Community}

Primarily findings from National Census on the living conditions of 53 ethnic minority groups in Vietnam (2015) show that the number of communes equipped with common places for cultural activities and the communication (speakers) system are 3501 (35.4\%) and 3946 (39.9\%) respectively by the end of July 2015 [9]. The most popular activities in which the ethnic minority groups attended in the free time are sleep and relax (mean value: 3.84), chatting with friends (mean value: 3.38). While the less one is accessing internet (mean value: 1.80). Some recreational activities are less frequent including reading news (mean value: 2.20 ), hanging around (mean value: 2.38 ) or coming back hometown (mean value: 2.41). It means that the minorities in urban pay more times and considerations on reproducing rather than attending the recreational activities to meet the social demands. So, from the Maslow approach to the social needs, these people are working for meeting the basic need with more priorities at the life experiences in the urban.

In terms of political and community participation, it is found that a majority of ethnic minorities joined in the local vote $(75.1 \%)$ and attended in the local meetings $(43.3 \%)$. Other activities in the urban attracted less frequent participation by ethnic minorities, in which there is low ratio of participating in the local groups and clubs, youth association's activities, and hometown fellow-men's groups. 
Table 5. Social network and local activities (\%).

\begin{tabular}{|c|c|c|c|c|c|c|c|}
\hline & \multirow{2}{*}{ Social network and local activities } & \multirow{2}{*}{ Being invited (\%) } & \multicolumn{5}{|c|}{ Participation level } \\
\hline & & & Min & Max & Mean & SD & Mode \\
\hline 1 & Community meeting & 43.3 & 1 & 5 & 2.76 & 1.48 & 1 \\
\hline 2 & Local voting & 75.1 & 1 & 5 & 2.96 & 1.19 & 3 \\
\hline 3 & Local festival & 41.7 & 1 & 5 & 2.53 & 1.21 & 3 \\
\hline 4 & Cultural and extra activities in local & 35.4 & 1 & 5 & 2.23 & 1.01 & 1 \\
\hline 5 & Workplace extra activities & 26.8 & 1 & 5 & 2.07 & 1.08 & 1 \\
\hline 6 & Charity activities & 26.8 & 1 & 5 & 2.10 & 1.10 & 1 \\
\hline 7 & Clubs & 8.7 & 1 & 5 & 1.68 & 0.94 & 1 \\
\hline 8 & Local associations & 18.6 & 1 & 5 & 1.88 & 1.01 & 1 \\
\hline 9 & Home country Fellow association & 10.4 & 1 & 5 & 1.67 & 0.92 & 1 \\
\hline
\end{tabular}

Source: Survey findings

In brief, it is found that the social services for urban are poor and presents the limitations in terms of lacking the principle on various and comprehensive forms, sharing between State and society, and among social groups; less encouragement of participation by the local organizations, industries, and local people for active participation; lack of linkage between planning and developing the actions for each social service; investment for enlarging the service provision system is less compatible and engagement with the general urban development plan. Many indicators for the social service development are out of date in comparing to the current conditions. The prominent reason for such limitation is that the quick urban development spread out the nationwide while the payment capacities by the ethnic minorities are left behind, and there is still limited in the State's supports for improving and enlarging the social services in urban. In additions, many local governments do not strictly follow the government guidelines and policies on developing the urban areas comprehensively with the setting up the social services for the urban peoples in general and for the ethnic minorities in particular. Other reason for such situation is that there is lack of supervised unit to control the quality of social services publicily, especially for those public ones, and there is no clear line to identify the role of governmental units on service provision and supervisions for extra activities by the third parties.

\subsection{Limitations for the Service Accessibilities by the Ethnic Minority Groups}

From literature reviews and survey responses, it is found that some barriers for such accessing are presented in the following reasons:

\subsubsection{High Pressure from Livelihood in the Urban}

Ethnic minorities face intensive pressure about their life in the urban, and such pressure increases gradually as the daily expenses in the new living conditions in urban. They spend more times on meeting the basic needs and for the livelihood. From the survey, it shows that it took the minorities around 9.14 hours per day for working in the workplaces, with the min value at 4 hours and max value at 15 hours (nearly two times of the normal working load). On the question of facing any social problems in the urban life, the problems with high responses by the ethnic minorities are "difficulty on finding the sustainable job", "pressure for being breadwinner for the family", and "employment competition". Around $23.9 \%$ of ethnic minorities in this research shared that due to the low monthly income (around 4 million VND, equal to 200 USD), their life is not sustainable, and they have to work in extra time, so they do not have enough time for cultural and recreational activities in their urban life.

\subsubsection{Limitation of Accessible Capacities to Social Services}

In spite of recent education improvement nationwide, qualification level of ethnic minority groups is still low and a clear gap between groups. Due to such education level, it took these groups more time on working but less productive and income. The following table shows the monthly income and the proportion of income sources of minority groups in Vietnam in comparison of educational levels of householders.

Table 6. Relation between householder's educational level and monthly income (\%).

\begin{tabular}{|c|c|c|c|c|c|}
\hline \multirow{2}{*}{$\begin{array}{l}\text { Householder's } \\
\text { educational levels }\end{array}$} & \multirow{2}{*}{$\begin{array}{l}\text { Monthly income for each } \\
\text { household member (1000 VND) }\end{array}$} & \multicolumn{4}{|c|}{ Income resources (\%) } \\
\hline & & Salary & $\begin{array}{l}\text { Agriculture, Forestry } \\
\text { and fishery }\end{array}$ & $\begin{array}{l}\text { Non-agriculture, forestry } \\
\text { and fishery }\end{array}$ & Other \\
\hline (A) & (1) & (2) & (3) & (4) & (5) \\
\hline Illiteracy & 1099.4 & 37.1 & 44.1 & 10.1 & 8.7 \\
\hline Primary level & 1157.6 & 36.1 & 45.4 & 11.0 & 7.5 \\
\hline Secondary level & 1265.5 & 38.5 & 41.6 & 12.9 & 7.0 \\
\hline High school & 1610.2 & 40.4 & 31.5 & 19.2 & 8.9 \\
\hline Elementary occupation & 2030.7 & 53.7 & 16.5 & 21.5 & 8.3 \\
\hline Vocational training & 1824.1 & 66.1 & 16.1 & 8.9 & 8.9 \\
\hline Professional training & 2245.3 & 59.7 & 19.6 & 7.2 & 13.5 \\
\hline
\end{tabular}




\begin{tabular}{llllll}
\hline \multirow{2}{*}{$\begin{array}{l}\text { Householder's } \\
\text { educational levels }\end{array}$} & $\begin{array}{l}\text { Monthly income for each } \\
\text { household member (1000 VND) }\end{array}$ & \multicolumn{2}{l}{ Income resources (\%) } \\
\cline { 3 - 6 } & Salary & $\begin{array}{l}\text { Agriculture, Forestry } \\
\text { and fishery }\end{array}$ & $\begin{array}{l}\text { Non-agriculture, forestry } \\
\text { and fishery }\end{array}$ & Other \\
\hline College & 2459.4 & 79.1 & 8.3 & 10.5 & 2.1 \\
Professional college & 2747.2 & 73.7 & 11.7 & 3.1 & 11.5 \\
University & 3732.8 & 71.5 & 8.0 & 5.7 & 14.8 \\
Master & 4780.5 & 90.1 & 4.9 & 0.2 & 4.8 \\
\hline
\end{tabular}

Source: [9]

\subsubsection{Less Success of Community and Government Supports About Social Service Accessibility of Ethnic Minority Groups}

The ethnic minority groups spend more time on working for livelihood and live under great pressure of employment and incomes, so their social network in the urban is so weak. They visit their relatives and friends less frequently (mean at 2.53). There is more frequent visit to the home country fellows (mean at 2.46), co-workers (mean at 2.57), however its statistics is still at low ratio. In the opposite directions, receiving visits from other stakeholders are less frequent, by relatives with mean at 2.22; by home country fellows with mean at 2.39); or co-workers with mean at 2.37. As living in such weak connection and network, the ethnic minorities face difficulty on giving and taking supports from others and from local government and community.

Ethnic minorities in urban have not received enough the local government supports during their inclusion. As facing difficulties in their life, they frequently dealt with by themselves (mean at 4.28), while ask for local government support and supports from local associations accounts for the low responses, with mean at 1.97 and 1.93 respectively. And there is less support from the local people for the ethnic minorities who are migrants as such mean is at 2.19. It leads to the discussion that the ethnic minority groups do not make the good connection and their engagement to the local people and local life in aspects of social activities (with local people) and in aspect of governmental administration (with local government and associations). In case of creating such connection, it is still unclear and weak to boost up the social trust of the ethnic minorities on looking for the support sources.

\subsubsection{Social Services in Urban Are Limited}

There are many difficulties for ethnic minorities on accessing the urban social services due to the limitation of the welfare and support system in Vietnam. It is caused by the quick urban development and enlarge nationwide while the social demand increased multiply and variously; the public supports and national budgets for improving the social services networks are still limited. In such contexts, many local governments do not follow strictly the governmental guidelines to have comprehensive and strategic plan to make and deliver the social services successfully (Chính phủ 2016). Social support models for ethnic minority groups in urban are not enough and less effective which also cause the multi-layer barriers for them to access in their daily life.

\section{Conclusions}

From these findings in literature review and survey in Vietnam, this paper draws the following conclusion as:

Firstly, it is suggested to have the continuity in renovating and updating the social service system for ethnic minority groups in urban: it means that the service providers pay more attention on enlarging the housing services and simplifying the procedures on service provision, related to the housing, for ethnic minorities in urban. In additions, the services on clean water and living environment are considered for this policy subjects. The government approves the policy to encourage the participation of non-governmental sectors on providing the basic services such as education for children, employment and vocational training for work forces in the ethnic minority groups in urban. In term of health care, it is recommended that the health care system from local levels encourages and coordinate with non-public sectors for providing the services in health check and treatments to improve the health quality for these groups with priority policies and supports.

Secondly, it is necessary to improve and strengthen the support activities for ethnic minority groups on accessing social services in urban: There are recommendations for improving the legal supports, advisory and communication activities about the possible policies in which the ethnic minority groups can take benefits and promotion the capacity on urban life. In additions, it is advised to restructure the public service system for providing the actual supports for ethnic minority groups in Vietnam with steps. At first, it is required to combine the support units in urban and in industrial zones to have two way support models from governmental organizations and the ethnic minority groups. In additions, for the long term purpose, training the qualified staff and promoting the local community's autonomy to work with ethnic minority groups successfully which lead to remove any restrictions on service provision for the ethnic minority groups, and to aim at constructing the equal life contexts for all.

Thirdly, it is required to improve the capacities on accessing the social services of ethnic minority groups in the urban life: The best and most sustainable way to support the ethnic minority groups in general and those in urban in particular is supporting them to self-improvement and resilience of their personal strengths and capacities. It means that the government should encourage the related parties and sides to provide the vocational training, employment 
activities and extra skill training for ethnic minority people rather than leave these tasks to the employers or the educational system. Besides, there are competitions and festivals to motivate and improve the working skills for the workforces of ethnic minorities which could enrich them with practical's kills and opportunities to follow the better jobs and higher income. Besides, it is necessary to organize the community work and cultural festivals to enlarge the interactions between groups and shared the same interests. The government also collects information from the regional countries to extract the good examples for Vietnam in supporting the ethnic minorities groups in the developing and globalization process.

\section{Acknowledgement}

The authors give the best thanks to Vietnam National Committee on Ethnic Minority Affairs on supporting the research project titled: Life of Ethnic Minority Groups in Urban and Industrial Zones in Vietnam: Current situation and proposal solutions (2016), number: ĐTCB. UBDT.05.16.

\section{References}

[1] Ashley, C và Carney D.1999. Sustainable Livelihoods: Lessons from early experience, London: Department for International Development.

[2] Bebbington, Anthony (1999), "Capitals and capabilities: A framework for analyzing peasant viability, rural livelihoods, and poverty", World Development, Vol. 27, No. 12, pp. 20122044.

[3] Bế Trường Thành. 2002. Vấn đề dân tộc và định huớng xây dưng chinh sách dân tộc trong thời kỳ công nghiệp hóa, hiện đại hóa/Ethnic issues and orientation for making the national ethnic policis in the industrialisation and modernisation process, Nxb Chính trị Quốc gia/National Political House, Hanoi.

[4] Chính phủ (2016) Chỉ thị số 24/ CT - TTg của Thủ tướng Chính phủ, ngày $02 / 8 / 2016$ về Việc tăng cuờng phát triển hệ thống dịch vu xã họi đô thị đảm bảo an sinh xã họi/Government (2016) Decree number 24/CT-TTg by PM dated $2 / 8 / 2016$ on Promoting the social services in urbans to meet the social welfare demands.

[5] DFID.1999. Sustainable Livelihoods Guidance Sheet, Xem ngày 7/9/2016 tại http://www.ennonline.net/dfidsustainableliving.

[6] Đinh Văn Ân, Hoàng Thu Hoà (2006), Đổi mói cung ứng dịch vu công ớ Việt Nam/Renovating the Public Services in Vietnam, General Statistic Publisher, Hanoi.

[7] Đỗ Thị Hải Hà (2007), Quản lý nhà nuoóc đối với cung úng dịch vu công/State Administration on service provision, Technic and Science Publisher, Hanoi.

[8] Filipe, Paulo (2005), The right to land a livelihood: The dynamics of land tenure systems in Conda, Amboim and Sumbe municipalities, Norwegian People's Aid.

[9] GSO (2016), Kết quả tù cuộc tổng điều tra thục trạng kinh tế
- xã hôi của 53 DTTS năm 2015/Findings from survey on life conditions of 53 ethnic minorities in Vietnam, GSO Publishing, Hanoi.

[10] Lã Thị Thu Thủy, Nguyễn Thị Phương Hoa. 2011. Thay đổi tâm lý của thanh niên công nhân xuất thân tì̀ nông thon/Psychological changes of young workers from rural areas, Social Science Publisher, Hanoi.

[11] Lê Bạch Dương, Nguyễn Thanh Liêm. 2011. Tù nông thôn ra thành phố: tác động kinh tế xã hội của di cu Việt Nam/From rural to urban: social, economic impacts oF migration in Vietnam. Social Sciences Publisher, Hanoi.

[12] Moser, Caroline (2008), "Assets and livelihoods: A framework for asset-based social policy", in: Assets, livelihoods, and social policy, edited by Caroline Moser and Anis A. Dani, The World Bank, pp. 43-81.

[13] Nguyễn Ngọc Hiến (chủ biên) (2002), Vai trò của nhà nuớc trong cung úng dịch vu công/Role of State on Public Service Provision, Culture and Information Publisher, Hanoi.

[14] Lê Chi Mai (2003), Cải cách dịch vu công ở Việt Nam/Renovation of Public Services in Vietnam, National Political House, Hanoi.

[15] Nguyễn Minh Phương (2013), Đẩy mạnh xã hội hoá giáo dục,

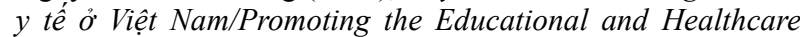
Socialisation in Vietnam, National Political House, Hanoi.

[16] Nguyễn Minh Tuấn. 2013. Đời sống của đồng bào dân tộc $\hat{E}$ đê trên địa bàn tỉnh Đắk Lăk-nhũng phân tích và so sánh xã họi hoc/Life experiences of Ede in Daklak province: Sociological Analysis and Comparison, PhD Thesis, Vietnam National University, Hanoi.

[17] Nguyễn Văn Chiều (2013). Chính sách an sinh xã hội và vai trò của nhà nuớc trong việc thực hiện chính sách an sinh xã hội ơ Viẹt Nam/Policies of Social Welfare and Role of State on Implementing the Social Welfare in Vietnam. PhD Thesis, Vietnam Academy of Social Sciences, Hanoi.

[18] Nguyễn Văn Nhật. (2010). Xây dưng và phát triển đời sống văn hoá của giai cấp công nhân Việt Nam: Một số vấn đề lý luận và thực tiê̂n/Making and developing the cultural life for worker class in Vietnam, Nxb Khoa học Xã hội/Social Science Publisher, Hanoi.

[19] Nguyễn Văn Quyết. (2013). Nghiên cứu sụ biến đổi văn hóa của các cộng đồng nông nghiệp - nông thôn trong quá trình phát triển các khu công nghiệp/Cultural changes of agricultural and rural communities in the industrial zones, Luận án tiến sĩ Văn hóa học/PhD thesis, Viện văn hóa nghệ thuật Việt Nam/Vietnam Institute of Culture and Arts, Hanoi.

[20] Nguyễn Văn Sửu (2010). Khung sinh kế bền vững-một cách phân tích toàn diện về phát triển và giảm nghèo/Sustainable Livelihood Framework: a comprehensive analysis on development and poverty alleviation, Tạp chi Dân tộc hoc/Ethnography Journal, No.2, pp.3-12.

[21] Phạm Văn Đức, Đặng Hữu Toàn, Nguyễn Đình Hòa. (2010). Vấn đề dân sinh và xã hội hài hòa/Social Welfare and Social Hamonisation. NXB Khoa học xã hội/Social Science Publisher, Hanoi.

[22] Phan Thị Mai Hương. 2010. Nhũng biến đổi tâm lý của cu dân vùng ven đô trong quá trình đô thị hoá/Psychological Changes of suburban people in the urbanisation, $\mathrm{Nxb}$ Từ điển Bách Khoa/Encyclopedia Publisher, Hanoi. 
[23] Tạ Thị Đoàn. 2011. Lao động, việc làm của công nhân trong các khu công nghiệp vùng kinh tế trọng điểm Bắc Bộ: Thực trang và nhüng hàm ý chính sách/Labor and Employment of workers in industrial zones in the northern important areas, Nxb Lao động/Labour Publishing House, Hanoi.

[24] Trần Nguyệt Minh Thu. 2014. Quá trình hoà nhập cộng đồng đô thị của ngườ lao động di cu tụ do tại Hà Nội/Community integration process of migrants in Hanoi. Luận án tiến sĩ/PhD thesis, Học viện khoa học xã hội/Vietnam Academy of Social Sciences, Hanoi.

[25] Trần Thanh Nam. 2001. Phát triển đời sống tinh thần của đồng bào dân tộc Khmer Nam Bộ trong công cuộc đổi mới hiẹn nay/Developing the cultural life for Khmer in Southern in the renovation process. Luận án Tiến sĩ/PhD Thesis, HVCTQG Hồ Chí Minh/Vietnam National Political Academy, Hanoi.

[26] Trần Văn Bính. 2004. Văn hóa các dân tộc Tây Bắc: Thưc trang và nhũng vấn đề đặt ra/Cultural life of ethnic groups in North West of Vietnam: Current Situation and Problems, Nxb Chính trị Quốc gia/National Political Publisher, Hanoi.

[27] Trần Văn Bính. 2006. Đời sống văn hóa các dân tộc thiểu số trong quá trình công nghiệp hóa, hiện đại hóa/Cultural life of Ethnic minorities in the industrialisation and modernisation, Nxb Lý luận Chính trị/Political Theory Publisher, Hanoi.
[28] Trần Văn Kham (2011). "Nghiên cứu về hoà nhập xã hội: một số vấn đề đặt ra cho Việt Nam/Research on Social Inclusion: Implications for Vietnam."Tap chí khoa hoc, ĐHQG Hà Nội/VNU Journal of Science 27(4): 37-47.

[29] Tran Van Kham, Pham Van Quyet (2015), Access to social services: how poor migrants experience their life in contemporary Vietnamese urban areas, Journal of Social Sciences and Humanities, Vol 1, No 3, pp. 277-290.

[30] Tran Van Kham, Pham Van Quyet (2015), Social inclusion of the poor migrants in the contemporary Vietnamese urban life, Social Sciences, 4 (6): 127-133.

[31] Vũ Văn Phúc. (2012). An sinh xã hội ở Việt Nam huoóng tới 2020/Vietnam Social Welfare to 2020. NXB Chính trị quốc gia/National Political Publisher, Hanoi.

[32] UNDP (2011) Dịch vu xã hội vì sự phát triển con người Social services for human development, accessed on $10 / 9 / 2016$ at http://www.undp.org/content/dam/vietnam/docs/Publications/ 27109_902_UNDP_Final_low_res_file_VN_310112.pdf.

[33] Wattez, EA.1999. Một số vấn đề về phát triển con người ở Việt Nam/Current issues for Human Development in Vietnam, NXB Sự thật/Su that Publisher, Hanoi. 